\title{
Photoperiod and temperature interaction in the determination of reproduction of the edible snail, Helix pomatia
}

\author{
Annette Gomot \\ Laboratoire de Zoologie et Embryologie, UA CNRS 687, Faculté des Sciences et Techniques et \\ Centre Universitaire d'Héliciculture, Université de Franche-Comté, 25030 Besançon Cedex, France
}

\begin{abstract}
Summary. Snails were kept in self-cleaning housing chambers in an artificially controlled environment. Mating was frequent under long days ( $18 \mathrm{~h} \mathrm{light)}$ and rare under short days $\left(8 \mathrm{~h}\right.$ light) regardless of whether the snails were kept at $15^{\circ} \mathrm{C}$ or $20^{\circ} \mathrm{C}$. An interaction between photoperiod and temperature was observed for egg laying. The number of eggs laid (45-50/snail) and the frequency of egg laying (90-130\%) were greater in long than in short days (16-35/snail and $27-77 \%$ ) but a temperature of $20^{\circ} \mathrm{C}$ redressed, to some extent, the inhibitory effect of short days. At both temperatures only long photoperiods brought about cyclic reproduction over a period of 16 weeks, confirming the synchronizing role of photoperiod on the neuroendocrine control of egg laying in this species of snail.
\end{abstract}

Keywords: edible snail; mating; egg laying; photoperiod; temperature

\section{Introduction}

The effects of photoperiod and temperature, which influence most reproductive cycles of animals of temperate regions, have given rise to a certain number of observations for pulmonate gastropods.

In basommatophorans, the influence of photoperiod and temperature on reproduction has been shown in four species of lymnaeids and planorbids (Imhof, 1973), in Melampus (Price, 1979), in Lymnaea stagnalis (Bohlken \& Joosse, 1982; Dogterom et al., 1984; Joosse, 1984) and in Bulinus truncatus (Bayomy \& Joosse, 1987).

In stylommatophorans, Lüsis (1966) demonstrated that changes in environmental conditions bring about modifications of the reproductive apparatus in Arion ater rufus while Sokolove \& McCrone (1978) showed a major role of long days on maturation of the genital apparatus of Limax maximus. Amongst snails, the species Helix aspersa, which has a wide geographic distribution, has been the object of studies showing the importance of photoperiod on the control of reproduction (Stephens \& Stephens, 1966; Bailey, 1981; Enée et al., 1982; Le Guhennec \& Daguzan, 1983; Gomot \& Deray, 1987).

In Helix aspersa, temperature is a limiting factor on spermatogenesis during hibernation (Gomot et al., 1986), but inhibition of reproduction by low temperature in this species can be, in part, compensated for by a long-day photoperiod (Gomot et al., 1989). In Cepaea nemoralis, the effect of photoperiod seems less pronounced than in Helix aspersa because Hunter \& Stone (1986) obtained egg laying in animals raised in short days just as well as those raised in long days, but the snails were subjected to alternating elevated temperatures $\left(23-28^{\circ} \mathrm{C}\right)$.

For the Roman or edible snail, Helix pomatia, there are only a few observations on its normal reproductive cycle (Tischler, 1973; Lind, 1988). This species, heavily exploited for gastronomic reasons, is declining in distribution in Europe where it is an endangered species (IUCN Invertebrate Red Data Book, 1983, 632 pp., International Union for Conservation of Nature and Natural 
Resources). This species does not adapt well to captivity and its successful domestication has not yet been achieved in spite of numerous attempts. However, trials in a controlled environment showed that, in long days, egg laying comparable to that in normal climatic conditions can be achieved (Gomot et al., 1987). We have therefore undertaken systematic study of the interaction of photoperiod and temperature on reproduction in this species.

\section{Materials and Methods}

Animals. The snails used for reproductive studies were adult animals collected from nature (alluvial plain, $200 \mathrm{~m}$ altitude, department of Haute-Saône, France) at the end of May. Unlike snails of the species Helix aspersa whose shell upturns at adult-hood (curling and hardening of the edge of the shell), that of the edible snail does not upturn. We also chose animals for which the edge of the shell was hard, indicating that the animal was not in the growth phase. The average diameter of the shell of collected animals was $4 \cdot 2 \mathrm{~cm}$ and the average weight was $24 \mathrm{~g}$.

Material. The housing chambers used for reproduction had a surface area of $1.5 \mathrm{~m}^{2}$ and did not contain soil and were self-cleaning by an automatic programmed new device (patented by University of Besançon No. 80.27 .741 and commercialized by Serbiolix SA, 25170 Pelousey, France). Each unit consists of three adjoining compartments: in the middle one, the self-cleaning system is suppressed and received an egg-laying box filled with earth taken from the collection site (brownish surface soil: slightly moist lime-rich clay, $\mathrm{pH} 8$ ). The density was $13 \mathrm{snails} / \mathrm{m}^{2}$ in each group.

The housing chambers were placed in four separate climatic rooms in which photoperiod, temperature and humidity can be programmed independently.

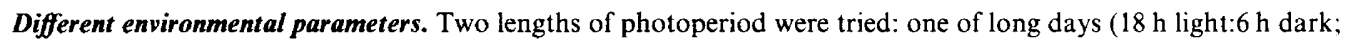
18L:6D) and the other of short days (8L:16D); Mazda FT40 fluorescent lamps were used.

The two temperatures tested were a constant temperature of $15^{\circ} \mathrm{C}$ and one of $20^{\circ} \mathrm{C}$. These variables gave rise to four groups containing snails subjected to long days and $20^{\circ} \mathrm{C}$ (Group A), long days and $15^{\circ} \mathrm{C}$ (Group B), short days and $20^{\circ} \mathrm{C}$ (Group C) and short days and $15^{\circ} \mathrm{C}$ (Group D). Two batches of 20 animals were used for each group.

Relative humidity was identical for all groups $(90-100 \%)$. The food was a special mix of cereal flour, mineral salts and vitamins (European Patent of CNRS No. 88.402.32.19) supplied by Serbiolix SA (25170 Pelousey, France). The food was distributed each morning after the automatic cleaning.

Observations. (a) For estimation of the mating percentage, each morning the numbers of pairs either in prelude or in post-copulation attitudes were counted. In fact, the mating itself is short (a few minutes) and has rarely been observed; however, the pre- and post-mating behavioural sequences are easily observable according to the description of Lind (1975). (b) Egg laying (clutches of eggs laid by each snail) was assessed each week to determine the rate of weekly reproduction (Fig. 1). At the end of the experiment, the overall rate of reproduction was evaluated. The number of eggs per laying was also counted, which permitted determination of the average number of eggs per snail. (c) Mortality was also evaluated by the percentage of snails dying during the experiment in each series.

\section{Results}

\section{Comparisons of the rate of total layings in the four groups}

Comparison of the rates of reproduction obtained in the different series (Table 1) shows clearly that the best reproduction and the greatest number of eggs per snail were obtained with long days at $20^{\circ} \mathrm{C}(\mathrm{LD} / 20)$ while snails kept in short days at $15^{\circ} \mathrm{C}(\mathrm{SD} / 15)$ laid very few eggs.

Table 1. Reproduction of edible snails under different combinations of photoperiod and temperature

\begin{tabular}{|c|c|c|c|c|c|c|c|c|}
\hline \multirow[b]{2}{*}{ Group } & \multicolumn{2}{|c|}{ Conditions } & \multirow{2}{*}{$\begin{array}{l}\text { Duration } \\
\text { of exp. } \\
\text { (weeks) }\end{array}$} & \multirow[b]{2}{*}{$\%$ mating } & \multirow{2}{*}{$\begin{array}{l}\text { Duration of } \\
\text { egg-laying } \\
\text { period } \\
\text { (weeks) }\end{array}$} & \multirow{2}{*}{$\begin{array}{c}\text { Rate of } \\
\text { total laying } \\
(\%)\end{array}$} & \multirow[b]{2}{*}{ Eggs/snail } & \multirow[b]{2}{*}{$\begin{array}{c}\text { Mortality } \\
(\%)\end{array}$} \\
\hline & Photoperiod & $\begin{array}{c}\text { Temperature } \\
\left({ }^{\circ} \mathrm{C}\right)\end{array}$ & & & & & & \\
\hline A & Long & 20 & 18 & $67 \cdot 5$ & 14 & 130 & 50 & 45 \\
\hline B & Long & 15 & 18 & 65 & 17 & 90 & 45 & $12 \cdot 5$ \\
\hline C & Short & 20 & 18 & $22 \cdot 5$ & 8 & $77 \cdot 5$ & 35 & $27 \cdot 5$ \\
\hline D & Short & 15 & 18 & 25 & 4 & $27 \cdot 5$ & 16 & $22 \cdot 5$ \\
\hline
\end{tabular}


Variation in the rate of laying over time in the different groups

Examination of Fig. 1 shows differences in the distribution of egg laying over time. For the snails in Group D that were kept in short days at $15^{\circ} \mathrm{C}$ and did lay, the eggs were laid during the first 4 weeks of the experiment and then laying ceased.

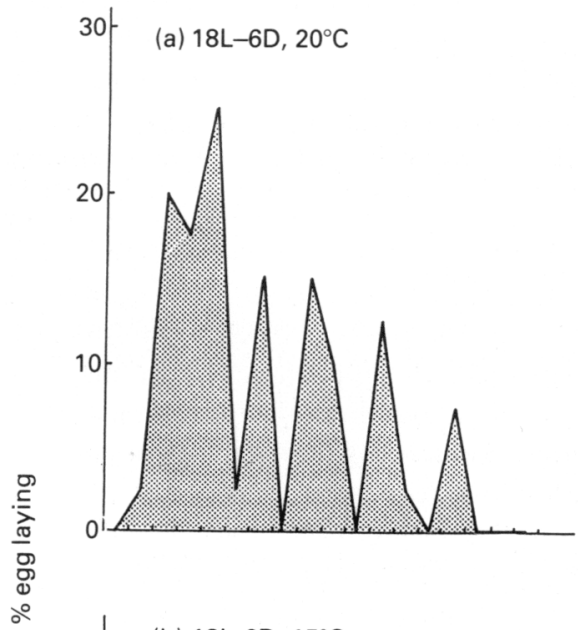

(b) $18 \mathrm{~L}: 6 \mathrm{D}, 15^{\circ} \mathrm{C}$

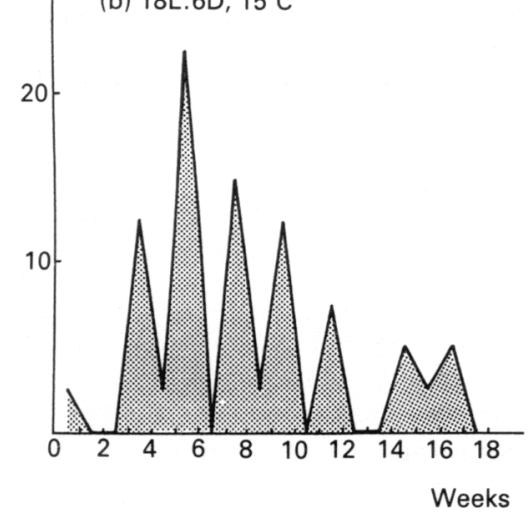

(c) $8 \mathrm{~L}: 16 \mathrm{D}, 20^{\circ} \mathrm{C}$

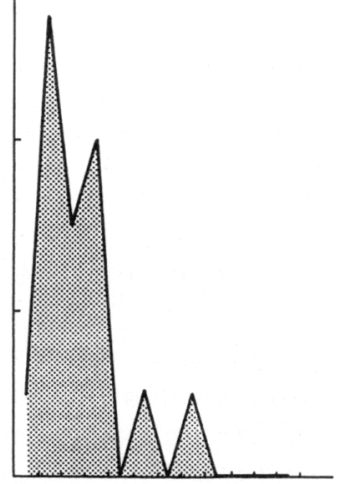

(d) $8 \mathrm{~L}: 16 \mathrm{D}, 15^{\circ} \mathrm{C}$

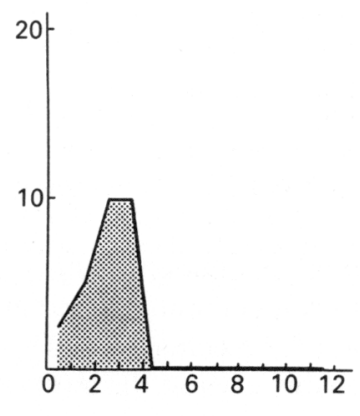

Fig. 1. Variations in the rate of reproduction as a function of time (weeks) in the different groups of snails.

In Group $\mathrm{C}$ snails (short days at $20^{\circ} \mathrm{C}$ ) laying was as prolific as in long days at $20^{\circ} \mathrm{C}$ (Group A) during the first 4 weeks, but then it decreased rapidly during the next 4 weeks and stopped completely in the 8 th week.

However, snails kept in long days (Groups A and B) exhibited a laying pattern that was cyclic and continued until the 15 th week at $20^{\circ} \mathrm{C}$ (Group A) and the 17 th week at $15^{\circ} \mathrm{C}$ (Group B). The rhythm of egg deposition in long days was about 2 weeks, maximum laying occurring at the 4th week at $20^{\circ} \mathrm{C}$ and 5 th week at $15^{\circ} \mathrm{C}$. Then there was progressive decrease in the value of laying 'peaks' until reproduction ceased.

\section{Effect of environmental conditions on mating}

The percentage of matings depended largely on photoperiod (Table 1). For each photoperiod, the percentage was essentially the same at $15^{\circ} \mathrm{C}$ as at $20^{\circ} \mathrm{C}$; it is much more important $(\times 2.6$ to $\times 3)$ 
in long days than in short days. In short-day conditions the matings stopped after 2 weeks at $15^{\circ} \mathrm{C}$ and after 3 weeks at $20^{\circ} \mathrm{C}$ whereas in long days they occurred until the 14 th week at $15^{\circ} \mathrm{C}$ and until the 12 th week at $20^{\circ} \mathrm{C}$.

\section{Comparison of the rate of mortality}

In short days, mortality was essentially of the same order (about $1 / 4$ animals) at both temperatures used and does not seem to bear any relation to the percentage of reproduction.

In long days, however, mortality was higher in snails which had a higher rate of reproduction. It was lower in the Group B snails for which the combination of long days and low temperature was compatible with a good survival rate and with average egg production per snail almost as good as in Group A.

\section{Discussion}

The present experiments confirm the fact that it is now possible to keep edible snails that reproduce in a controlled environment. They also demonstrate the importance of an interaction between the factors of daily lighting and temperature in the determination of reproduction.

Only the long-day photoperiod was able to induce a prolonged reproduction cycle for 15-17 weeks (Figs la and b). In the short-day photoperiod, egg laying was very rapidly inhibited at $15^{\circ} \mathrm{C}$ (Group D) and limited to 8 weeks at $20^{\circ} \mathrm{C}$.

Comparison of the sensitivity to photoperiod of Helix pomatia with that of Helix aspersa aspersa and Helix aspersa maxima studied by Bonnefoy-Claudet \& Deray (1987) shows that the relationship of rate of reproduction in long days/rate of reproduction in short days is 4.05 in Helix aspersa aspersa and 1.9 in Helix aspersa maxima. In Helix pomatia, this relationship equals 3.3 at $15^{\circ} \mathrm{C}$ and 1.7 at $20^{\circ} \mathrm{C}$. Each of the species, therefore, has a particular sensitivity to photoperiod and temperature.

These experiments also indicate that the physiological factors that control mating and laying are not identical and that there is no direct correlation between the two phenomena. Matings are only sensitive to photoperiod; they are numerous in long days and rare in short days regardless of temperature.

Finally, as in many animals, light is the principal synchronizing factor (Dumortier, 1981) and photoperiod has a role comparable to that which it plays in the conditioning of reproduction in many vertebrates (Benoit \& Assenmacher, 1970). Intermediate mechanisms in the effect of photoperiod and temperature probably exist at the level of functioning of the genital apparatus as in Helix aspersa (Gomot et al., 1989) or at the level of production of the egg-laying hormone, unidentified in snails, but whose synthesis is inhibited by short photoperiods and low temperature in Lymnaea stagnalis (Joosse, 1984). Other mediating substances such as secretions of the dorsal bodies (Saleuddin et al., 1983) or prostaglandins in Helisoma (Kunigelis \& Saleuddin, 1986) could be involved. Further investigations are necessary to determine the mode of action of photoperiod and temperature on the neuroendocrine system of Helix pomatia. Up to now, the results presented form a basis for a rational method of raising a species in danger of becoming extinct.

We thank Professor A. S. M. Saleuddin for help with the English; A. Deray and L. Gomot for fruitful discussions during the experiments; and Professor C. R. Marchand for his co-operation.

This research was supported by grants (84-H-518) from Ministère de la Recherche et de l'Enseignement Supérieur.

\section{References}

Bailey, S.E.R. (1981) Circannual and circadian rythms in the snail Helix aspersa Müller and the photoperiodic control of annual activity and reproduction. J. comp. Physiol. 142, 89-94.
Bayomy, M.F.F. \& Joosse, J. (I987) Effects of temperature and photoperiod on egg laying, body growth and survival of Bulinus truncatus. Proc. Kon. Ned. Akad. Wet. 90, 243-256. 
Benoit, J. \& Assenmacher, I. (1970) La photorégulation de la reproduction chez les Oiseaux et les Mammifères. Coll. intern. CNRS, No. 172, Montpellier, Editions du CNRS, Paris, 588 pp.

Bohlken, S. \& Joosse, J. (1982) The effect of photoperiod on female reproductive activity and growth on the freshwater snail Lymnaea stagnalis kept under laboratory breeding conditions. Int. J. Invert. Reprod. 4, 213-222.

Bonnefoy-Claudet, R. \& Deray, A. (1987) Modalités de reproduction de l'escargot Helix aspersa maxima en fonction de la photophase: comparaison avec Helix aspersa aspersa. Haliotis 16, 69-75.

Dogterom, G.E., Hofs, H.P., Wapenaar, P., Roubos, E.W. \& Geraerts, W.P.M. (1984) The effect of temperature on spontaneous and ovulation hormoneinduced female production in Lymnaea stagnalis. Gen. comp. Endocrinol. 56, 204-209.

Dumortier, B. (1981) Le cerveau photorécepteur. La Recherche 123, 722-731.

Enée, J., Bonnefoy-Claudet, R. \& Gomot, L. (1982) Effets de la photopériode artificielle sur la reproduction de l'escargot Helix aspersa Müller. C. r. hebd. Séanc. Acad. Sci. Paris 294, 357-360.

Gomot, A., Gomot, P. \& Deray, A. (1987) Modalités de reproduction de l'escargot Helix pomatia en parc externe et en conditions hors sol contrôlées. Haliotis 16, $93-10$ l.

Gomot, L. \& Deray, A. (1987) Les escargots. La Recherche 186, 302-311.

Gomot, P., Gomot, L. \& Griffond, B. (1989) Evidence for a light compensation of the inhibition of reproduction by low temperatures in the snail Helix aspersa. Ovotestis and albumen gland responsiveness to different conditions of photoperiods and temperatures. Biol. Reprod. 40, 1237-1245.

Gomot, P., Griffond, B. \& Gomot, L. (1986) Effets de la température sur la spermatogenèse d'escargots Helix aspersa maintenus en repos artificiel. C. r. hebd. Séanc. Acad. Sci. Paris 302, 27-32.

Hunter, R.D. \& Stone, L.M. (1986) The effect of artificial photoperiod on growth and reproduction in the land snail Cepaea nemoralis. Int. J. Invert. Reprod. Dev. 9, $339-344$.
Imhof, G. (1973) Der Einfluss von Temperatur und Photoperiode auf den Lebenszyklus einiger Susswasserpulmonaten. Malacologia 14, 393-395.

Joosse, J. (1984) Photoperiodicity, rhythmicity and endocrinology of reproduction in the snail Lymnaea stagnalis. In Photoperiodic Regulation of Insect and Molluscan Hormones (Ciba Fdn Symp. 104), pp. 204-220. Pitman, London.

Kunigelis, S.C. \& Saleuddin, A.S.M. (1986) Reproduction in the freshwater gastropod Helisoma: involvement of prostaglandin in egg production. Int. J. Invert. Reprod. Dev. 10, 159-167.

Le Guhennec, M. \& Daguzan, J. (1983) Rôle de la lumière sur la reproduction de l'escargot Petit Gris, Helix aspersa Müller. C. r. hebd. Séanc. Acad. Sci. Paris 297, 141-144.

Lind, H. (1975) Mating behaviour of Helix pomatia. Behaviour 59, 163-202.

Lind, H. (1988) The behaviour of Helix pomatia L. (Gastropoda, Pulmonata) in a natural habitat. Vidensk. Meddr dansk naturh. Foren. 147, 67-92.

Lüsis, O. (1966) Changes induced in the reproductive system of Arion ater rufus by varying environmental conditions. Proc. Malacol. Soc. Lond. 37, 19-26.

Price, C.H. (1979) Physical factors and neurosecretion in the control of reproduction in Melampus (Mollusca: Pulmonata). J. exp. Zool. 207, 269-282.

Saleuddin, A.S.M., Farrel, C.L. \& Gomot, L. (1983) Brain extract causes amoeboid movement in vitro in oocytes in Helix aspersa (Mollusca). Int. J. Invert. Reprod. Dev. 6, 31-34.

Sokolove, P.G. \& McCrone, E.J. (1978) Reproductive maturation in the slug Limax maximus and the effects of artificial photoperiod. J. comp. Physiol. 125, 317-325.

Stephens, G.J. \& Stephens, G.C. (1966) Photoperiodic stimulation of egg laying in the land snail Helix aspersa. Nature, Lond. 212, 1582.

Tischler, W. (1973) Zur Biologie und Ökologie der Weinbergschnecke (Helix pomatia). Faun. Ökol. Mitt. 4, 283-298.

Received 27 March 1990 